\title{
Adoption of cleaner production in a pupunha palm heart factory: a systematic literature review and a case study
}

\author{
Walter Augusto VARELLA ${ }^{1}$, Geraldo Cardoso de OLIVEIRA NETO ${ }^{1 \star ~(D), ~ T h a l e s ~ B o t e l h o ~ d e ~ S O U S A ~}{ }^{1}$
}

\begin{abstract}
The pupunha (peach palm) palm heart production in the Vale do Ribeira (southern region of the State of São Paulo-Brazil) brings economic benefits to the region, and environmental risks with the generation of a large amount of waste. The Cleaner Production adoption in the pupunha palm heart factories is a strategy for reducing environmental impacts and generating profit, with consequent rational use of raw material, reuse of waste, and new equipment installation. This research aims to evaluate the Cleaner Production adoption's environmental and economic benefits in the reuse of waste generated in pupunha palm heart processing. The case study was carried out in a factory, using direct observation, interviews, and documentary data. The calculation of ROI was an adequate tool for economic evaluation, and the adoption of gondolas in the stages of material separation and waste treatment provided improvements in the production processes. The Cleaner Production application increased the theoretical knowledge about the treatment and use of the waste, reduced the environmental impact, allowed the development of a new business, and generated economic gains through the creation of employment and increase of income.
\end{abstract}

Keywords: economic and environmental evaluation; cleaner production; solid waste; pupunha (Peach Palm).

Practical Application: Cleaner Production in pupunha palm heart factory resulted in sustainability.

\section{Introduction}

In recent years, the world population's growth has forced an increase in food production, which causes greater consumption of natural resources, energy, and water and changes the environmental, social, and economic conditions (Elliot, 2006). Therefore, initiatives for managing water use (Goap et al., 2018), energy (De Laurentiis et al., 2016), and best practices for integrated resource management (Mannan et al., 2018) are essential for sustainable development (Chen et al., 2019).

According to Ramos et al. (2018), sustainability practices that allow for increased process efficiency in industries with mitigation and reduced risks to the environment and society are the focus of Cleaner Production.

According to Ianovali et al. (2018), in the 1990s, quilombola farmers from Vale do Ribeira, a region located on the south coast of the São Paulo State-Brazil, started to extract the palm heart from the peach palm (Bactrisgasipaes Kunth), as the juçara (Euterpe Edulis Martius) became an endangered species. Several factories of pupunha palm heart processing were installed in the region, generating employment and income.

According to Kapp et al. (2003), the pupunha palm heart has simple processing, starting with the peeling process, which generates large amounts of waste, followed by filling in pots, and finally, the cooking of these pots in tanks, a stage in which large amounts of water are discarded.
The Cleaner Production (CP) can be classified as a set of rules and preventive actions that allows the continued application of a system aimed at financial and environmental results through the rational use of raw materials and the reuse of natural or industrialized residual resources (Jabbour, 2010). The CP seeks to promote means to improve industries' operational efficiency through waste reduction, processes optimization, and an environmentally correct view (Hamner, 1996). Developed through a joint effort by the United Nations Environment Program (UNEP) and the United Nations Industrial Development Organization (UNIDO), the CP represents an essential method to promote the sustainable development of society (Massote \& Santi, 2013). According to Oliveira et al. (2016), CP was introduced in Brazil in 1995 by creating the Centro Nacional de Tecnologias Limpas (CNTL) or National Center for Clean Technologies.

A literature review on CP use in food industries presents several initiatives for the treatment of residues generated in the production processes, such as the production of chemicals, materials, and fuels from residues (Sáez-Martínez et al., 2016), generation of biogas through anaerobic digestion from residues rich in organic matter (Ingrao et al., 2018), and use of residues from the cider industry to generate value-added chemicals and fuel (Sette et al., 2020).

In anaerobic digestion processes in lactic acid fermentation, through $\mathrm{CP}$, wastewater from the production processes is transformed into biogas and reused in the processes (Zhang et al., 2019). 
According to Dvarionienè et al. (2012), in milk production, $\mathrm{CP}$ improves the process efficiency by acquiring equipment for the treatment of wastewater, allowing energy reduction, time, washing materials, and water consumption. Willers et al. (2014) implemented CP initiatives in a dairy farm, reducing water consumption when using pressurized water and dry cleaning of surfaces.

In the scientific literature, no studies were found on the application of $\mathrm{CP}$ practices to reuse residues from the pupunha palm heart industry. Based on this gap, this research aims to evaluate the environmental and economic benefits of adopting $\mathrm{CP}$ practices in the reuse of waste from a processing factory of pupunha palm heart. The resolution of the environmental liability with the commercialization of waste represents a contribution to the literature and management practice of palm heart processing industries.

This paper contains seven sessions, introduction, literature review, methodology, case study, results, discussion, and conclusion.

\section{Literature review}

\subsection{Application of Cleaner Production in the food industry}

Table 1 presents the papers presented in the literature review on CP use for managing wastes of the food industry. Waste and uncontrolled use of natural resources have drawn environmental experts and non-governmental organizations' attention to the need for the government to demand more effective control actions (Giannetti \& Almeida, 2006). The agriculture and food sectors are vital to human health and well-being, and food production's sustainability is a significant concern today (Medici et al., 2020).

Food waste is a significant barrier to a sustainable society (Aschemann-Witzel et al., 2020). In 2015, the Japanese food-processing industry generated 9.5 million tons of organic waste annually, of which $25 \%$ was composted or used as an intermediate material for the production of animal feed, $25 \%$ was dried, 5\% was used for energy generation, and $40 \%$ was incinerated or landfilled (Liu et al., 2016). Neugebauer \& Sołowiej (2017) state that in 2013 only 3\% of food wastes are recycled in the USA, and researches analyzing various waste management scenarios demonstrated that up to $27 \%$ of waste could be effectively composted.

According to Tesfaye et al. (2018), the disposal of large food waste poses substantial environmental impacts, and there is growing attention to it due to its effect on the environment (Tesfaye et al., 2020). CP is the most effective approach for avoiding waste (Aschemann-Witzel et al., 2020). The generation of waste from the agro-processing industry is continually increasing due to the increasing need for food security. The beneficiation of this waste has both economic and environmental impacts that can be overcome via the implementation of $\mathrm{CP}$ technologies (Tesfaye et al., 2020).

Industries that seek to implement CP practices need to pay special attention to the environmentally correct disposal of waste or its reuse. These procedures involve the interaction and interrelation of the industrial departments, which can also be reflected in the scope of economic and social issues (Oliveira et al., 2013).

According to Ingrao et al. (2018), the growing demand for food and the reduced adverse impacts of related supply chains represent a significant challenge in the $21^{\text {st }}$ century. According to the European Union, food waste increased substantially, and it was estimated that 126 million tonnes could be produced in 2020 (Tesfaye et al., 2020). As food waste at the consumer level is a recent research topic, the related factors are still under analysis and discussion, and waste can be a valuable resource for producing chemicals, materials, and fuels (Sáez-Martínez et al., 2016). Recycling of waste from food processing industries can also be in the form of livestock feed or by producing value-added products from the waste, as food wastes contain organic materials that are biodegradable and can be converted to bio-based materials (Tesfaye et al., 2020).

Denham et al. (2016) analyzed the environmental impacts of the fish fillet sector and reported that electricity consumption, leakage of refrigeration gas, and disposal of unused fish portions contributed to the higher greenhouse gas emissions in supply chains. Potential strategies of $\mathrm{CP}$ to reduce these impacts included installing solar panels, recycling fish fillet residues through the production of biogas, fertilizers, and hydrolysates, maintaining refrigeration equipment, and replacing gas. Together, these strategies can reduce up to $35 \%$ of the total greenhouse gas emissions in the fillet's collection, processing, and retail.

Wu et al. (2016) investigated four filtration treatments that improve the effluent quality of sorting/classification of canned tangerine. The treatment involved a bag filter, an activated carbon filter, and a precision filter, resulting in improved water quality. The efficiency of this process can provide a $34.28 \%$ reduction in consumption.

Sette et al. (2020) propose the full, effective, and sustainable use of bio-waste from the regional cider and wine industries as an incentive to CP. The residues were recovered by extracting bioactive compounds and the pyrolysis/gasification of the residual solid to obtain value-added chemicals. One of them is biochar, a product that can be used as a fuel, as a precursor to activated carbon, or as a substitute fertilizer, offering an advanced biological carbon sequestration option.

Adazabra et al. (2016) used instrumental methods to study the adequacy of the use of shea waste in the civil construction sector. Evidence suggested that the waste reused in unburned bricks provided stronger and most resistant walls to waterlogging in traditional buildings.

Jin et al. (2016) developed a systematic biotechnological approach to select suitable fungi for bioconversion of the winery biomass wastes (grape marc and lees) into animal feed, aiming to improve protein contents, and the digestibility of the grape marc. Bioconversion of organic waste materials, such as the grape marc and wine lees, to value-added products, offers an opportunity for the reuse of abundant waste materials from agro-industrial processes and can be an excellent process to improve the nutrition content and digestibility of the organic wastes, making them as protein-rich animal feedstock. 
Table 1. Application of CP in the food industry.

\begin{tabular}{|c|c|c|c|c|c|c|c|}
\hline Author(s) & Country & Factory & Waste Type & $\begin{array}{l}\text { Percentage of } \\
\text { solid waste }\end{array}$ & Waste Treatment & Economic Gain & $\begin{array}{l}\text { Environmental } \\
\text { Gain }\end{array}$ \\
\hline $\begin{array}{l}\text { Denham et al. } \\
(2016)\end{array}$ & Australia & Fish fillet & $\mathrm{CO}_{2}$ & ------------- & Biogas production & $\begin{array}{l}\text { Decrease in water } \\
\text { and energy costs }\end{array}$ & $\begin{array}{l}\text { Reduction of } 35 \% \\
\text { in greenhouse gas } \\
\text { emissions }\end{array}$ \\
\hline Wu et al. (2016) & China & Canned tangerine & Wastewater & --------------- & $\begin{array}{l}\text { Installing activated } \\
\text { carbon filters }\end{array}$ & $\begin{array}{l}\text { Water treatment } \\
\text { cost savings }\end{array}$ & $\begin{array}{l}\text { Decreased water } \\
\text { consumption }\end{array}$ \\
\hline Sette et al. (2020) & Argentina & $\begin{array}{l}\text { Grape and apple } \\
\text { wine }\end{array}$ & $\begin{array}{l}\text { Green apple } \\
\text { pomace, grape } \\
\text { pomace }\end{array}$ & $\begin{array}{l}100 \% \text { of } \\
\text { discarded } \\
\text { fruits }\end{array}$ & $\begin{array}{l}\text { Extraction } \\
\text { of bioactive } \\
\text { compounds, } \\
\text { gasification of the } \\
\text { residual solid and } \\
\text { obtaining added } \\
\text { value chemicals }\end{array}$ & $\begin{array}{l}\text { Activated carbon } \\
\text { production for } \\
\text { use in fuel and } \\
\text { reinforcement } \\
\text { applications in the } \\
\text { soil structure }\end{array}$ & $\begin{array}{l}\text { Elimination of } \\
\text { accumulation } \\
\text { of organic waste } \\
\text { from industries }\end{array}$ \\
\hline $\begin{array}{l}\text { Adazabra et al. } \\
(2016)\end{array}$ & Ghana & Shea production & Spent shea & 50 to $75 \%$ & $\begin{array}{l}\text { Use in the } \\
\text { manufacture of } \\
\text { clay bricks }\end{array}$ & $\begin{array}{l}\text { Bricks used in } \\
\text { building stronger } \\
\text { walls }\end{array}$ & $\begin{array}{l}\text { Reduction of } \\
\text { disposal and non- } \\
\text { use of waste }\end{array}$ \\
\hline Jin et al. (2016) & Australia & Wine industry & $\begin{array}{l}\text { Grape marc } \\
\text { and lees }\end{array}$ & $\begin{array}{l}\text { Not } \\
\text { mentioned }\end{array}$ & $\begin{array}{l}\text { Extraction of fungi } \\
\text { for producing } \\
\text { protein-rich } \\
\text { animal feedstock }\end{array}$ & $\begin{array}{l}\text { Increased protein } \\
\text { and digestibility of } \\
\text { animal feedstock }\end{array}$ & $\begin{array}{l}\text { Reduced carbon } \\
\text { emission of } \\
\text { landfills in } \\
\text { Australia. }\end{array}$ \\
\hline \multirow[t]{2}{*}{$\begin{array}{l}\text { Tesfaye et al. } \\
\text { (2018) }\end{array}$} & Ethiopia & $\begin{array}{l}\text { Mango juice- } \\
\text { making industry }\end{array}$ & $\begin{array}{l}\text { Solid waste } \\
\text { (mango seeds) }\end{array}$ & $\begin{array}{l}15 \text { to } 25 \% \text { of } \\
\text { the fruit }\end{array}$ & $\begin{array}{l}\text { Manufacturing of } \\
\text { starch from mango } \\
\text { seeds }\end{array}$ & $\begin{array}{l}\text { Accounting rate of } \\
\text { return of } 83 \%\end{array}$ & $\begin{array}{l}\text { Reduction in the } \\
\text { environmental } \\
\text { loads in traditional } \\
\text { processing }\end{array}$ \\
\hline & & & & & & $\begin{array}{l}59 \% \text { reduction of } \\
\text { unit production } \\
\text { cost compared to } \\
\text { maize }\end{array}$ & $\begin{array}{l}\text { Use of small } \\
\text { amounts of } \\
\text { chemicals in the } \\
\text { processing }\end{array}$ \\
\hline \multirow[t]{2}{*}{$\begin{array}{l}\text { Tesfaye et al. } \\
(2020)\end{array}$} & Ethiopia & Avocado farm & $\begin{array}{l}\text { Solid waste } \\
\text { (avocado seeds) }\end{array}$ & $\begin{array}{l}20 \text { to } 25 \% \text { of } \\
\text { the fruit }\end{array}$ & $\begin{array}{l}\text { Manufacturing } \\
\text { of starch from } \\
\text { avocado seeds }\end{array}$ & $\begin{array}{l}\text { Accounting rate of } \\
\text { return of } 75 \%\end{array}$ & $\begin{array}{l}\text { Reduction in } \\
\text { the amounts of } \\
\text { chemicals used } \\
\text { in the starch } \\
\text { extraction process }\end{array}$ \\
\hline & & & & & & $\begin{array}{l}40 \% \text { reduction } \\
\text { of selling price } \\
\text { compared to corn } \\
\text { starch }\end{array}$ & $\begin{array}{l}\text { Processing of } \\
\text { wastes generated }\end{array}$ \\
\hline $\begin{array}{l}\text { Zhang et al. } \\
(2020)\end{array}$ & China & Wheat starch & Wastewater & -------------- & $\begin{array}{l}\text { Nutrient } \\
\text { extraction from } \\
\text { wastewater }\end{array}$ & $\begin{array}{l}\text { Production of } \\
\text { vitamin } \mathrm{K}_{2} \text { using } \\
\text { Bacillus from } \\
\text { compounds } \\
\text { present in } \\
\text { wastewater }\end{array}$ & \\
\hline $\begin{array}{l}\text { Abou-Elela et al. } \\
(2008)\end{array}$ & Egypt & Confectionery & Wastewater & ------------ & $\begin{array}{l}\text { Chemical and } \\
\text { biological } \\
\text { treatment }\end{array}$ & $\begin{array}{l}\text { Saving financial } \\
\text { resources for the } \\
\text { construction of a } \\
\text { water treatment } \\
\text { plant }\end{array}$ & $\begin{array}{l}\text { Elimination } \\
\text { of untreated } \\
\text { wastewater } \\
\text { discharge into } \\
\text { the public sewage } \\
\text { system }\end{array}$ \\
\hline $\begin{array}{l}\text { Dvarionienè et al. } \\
\text { (2012) }\end{array}$ & Lithuania & Milk processing & Wastewater & 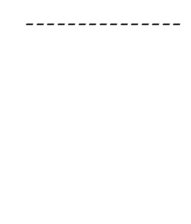 & $\begin{array}{l}\text { Use of water } \\
\text { treatment } \\
\text { equipment }\end{array}$ & $\begin{array}{l}\text { Reduction of } \\
40 \% \text { in energy } \\
\text { consumption, } \\
68 \% \text { in washing } \\
\text { materials, and } \\
57 \% \text { in electricity }\end{array}$ & $\begin{array}{l}\text { Reduction of } \\
9 \% \text { in pollutant } \\
\text { emissions, and } \\
31 \% \text { in water } \\
\text { consumption }\end{array}$ \\
\hline $\begin{array}{l}\text { Willers et al. } \\
(2014)\end{array}$ & Brazil & Dairy farm & Wastewater & --_--o- & $\begin{array}{l}\text { Training in } \\
\text { water use and } \\
\text { replacement } \\
\text { of cleaning } \\
\text { equipment }\end{array}$ & $\begin{array}{l}\text { Reduction of } \\
\text { additional water } \\
\text { and equipment } \\
\text { costs }\end{array}$ & $\begin{array}{l}\text { Reduction of water } \\
\text { consumption and } \\
\text { final amount of } \\
\text { polluting waste }\end{array}$ \\
\hline
\end{tabular}


Tesfaye et al. (2018) analyzed mango seeds as an alternative resource for starch production in Ethiopia. The results showed that starch extraction from mango seeds was facile, a good quality product was obtained, the unit production cost is $0.33 \mathrm{US} \$ / \mathrm{kg}$, while the cost of starch from maize is $0.81 \mathrm{US} \$ / \mathrm{kg}$, the project is financially viable with an accounting rate of return of $83 \%$ and a break-even analysis of $78 \%$ with a payback period of 2 years.

Tesfaye et al. (2020) analyzed avocado seeds as an alternative resource for starch production in Ethiopia. The results showed that starch extraction from avocado seeds is economically feasible, as it does not need sophisticated technology, has an accounting rate of return of $75 \%$, and a break-even analysis of $82 \%$ with a payback period of 2 years.

Zhang et al. (2020) studied the wheat starch sector, where wastewater was used to produce vitamin $\mathrm{K}_{2}$, using Bacillus subtilis $\mathrm{W}-17$, in order to reduce its production cost. The vitamin production through the extraction of nutrients from wastewater and its reuse can offset the sector's disposal costs.

Abou-Elela et al. (2008) studied wastewater management in a confectionery that produces chocolates, chewing gum, and lollipops, using cocoa butter, powdered milk, starch, sugar, flavors, and coloring compounds. The CP measures applied involved good cleaning, recovery of spent chocolate, modification of floor cleaning, and suction devices installation to remove sugar and powdered starch. With these initiatives, the money destined for the construction of a treatment plant wastewater has been spared.

Dvarionienè et al. (2012) demonstrated the application of $\mathrm{CP}$ and Ecological Design as sustainable production tools to improve a milk processing industry's environmental efficiency. Through more sophisticated equipment to deal with wastewater management, it was possible to achieve a $40 \%$ reduction in thermal energy consumption, $40 \%$ in time, $68 \%$ in washing materials, $57 \%$ in electricity, $9 \%$ in pollutant emissions, $31 \%$ in water consumption, and $9 \%$ in natural gas consumption.

Willers et al. (2014) studied the milking sector of a medium-sized dairy farm. CP actions implemented involved pressurized water, dry cleaning, and foam to clean surfaces; training employees to use water; replacing equipment cleaning; effluent decontamination; and fertilizer irrigation with wastewater.

Worldwide, Brazil stands out in the industrialization of acidified and pasteurized canned palm heart, both for the quantity processed and the product's quality (Berbari et al., 2008). Brazil is the world's largest producer and consumer of palm heart and is the second-largest exporter of this item (Belniaki et al., 2020).

According to Ormenese et al. (2016), concerning the palm trees that can be used in palm heart production, the species that stand out are juçara (Euterpe Edulis Martius), açaí (Euterpe Oleraceae Martius), pupunha/peach palm (Bactrisgasipaes Kunth), and several species of Australian royal palms (Archontophoenix Alexandrae and Archontophoenix Cunninghamiana are the most cultivated).

The Australian royal palm is an endemic tree in eastern Australia; however, it has developed well in Brazil, as the country's tropical climate provides an ideal temperature range (between
20 and $30^{\circ} \mathrm{C}$ ) for plant germination (Zanini et al., 2020). This specimen can reach up to 25 meters in height, producing viable seeds, having good resistance to diseases, and providing high-quality palm heart.

Pupunha is a multi-stemmed palm species used in the consumption of palm heart and the production of drinks, sweets, flour, among other products (Mossanek et al., 2014). Peach palm is a palm tree of tropical climate, is highly valued, as all its parts can be used, with the palm heart and the fruits having the highest added economic value (Clement \& Bovi, 1999).

When analyzing the agribusiness exploitation and the processes related to the industrialization of the pupunha palm heart, it is possible to observe the residual generation of large quantities of barks and their respective external sheaths, which, if not adequately cared for and discarded, can cause environmental problems (Silva et al., 2009).

According to Zanini et al. (2020), high palm production results in significant amounts of waste during palm heart extraction. For each palm, approximately $400 \mathrm{~g}$ of commercial palm heart is collected. The residue constitutes 80 to $90 \%$ of the palm's total weight, with some variation depending on the species. In the palm heart extraction process, the leaves are left at the cut site, and the stem is taken to the palm heart factory. The sheath has a high carbon/nitrogen ratio. Therefore, it takes time to decompose, causing environmental problems due to the accumulation of waste.

Palm residues are found in large quantities in several countries, mainly in Brazil, and are considered low-cost, biodegradable, and easy to handle waste (Zanini et al., 2020). Besides, pupunha palm heart can be sold through simplified processing steps. So, the peach palm is a palm highly valued in Brazil because, in addition to providing alternatives for sustainable cultivation, it generates employment and income for small and medium-sized farmers (Ferreira et al., 1982; Ianovali et al., 2018).

\section{Research method}

This research used case study as a method to understand facts and relationships (Gil, 2009), and according to Yin (2009), case study adoption aims to answer questions of "how" and "why", and in real situations where boundaries between the subject and the context are indistinct. Such conditions fit this research and confirm that the case study is the most appropriate method.

For this research, a single case study was carried out. The authors followed the following selection criteria:

1) To operate in the processing segment of pupunha palm heart;

2) To have adopted or to be in the process of implementing $\mathrm{CP}$

3) To allow researchers access to company information;

4) To make available a person responsible for supporting researchers on the $\mathrm{CP}$ adoption. 
It is noteworthy that the systematic literature review was initially developed to verify whether the case presented in this study would contribute to the scientific literature, demonstrating novelty. The procedures for data collection and data analysis adopted in the case study presented were explained.

\subsection{Systematic literature review}

In order to assess the economic and environmental benefits of using CP in the pupunha palm heart industry, exploratory research was carried out in the literature review in order to help understand subjects and events where there is little or no control (Marconi \& Lakatos, 2010). For that, a research protocol was elaborated using the terms "Cleaner Production" AND "Waste" OR "Residue" AND "Food", consulted in the databases Scopus and Web of Science. As criteria for selecting papers, filters were applied (papers published in journals, written in English, and with full text available). The criteria for rejection of papers were not to be applied CP with a focus on food production and waste reuse environments. However, although bibliographic research in the Scopus and Web of Science databases revealed 81 papers on wastes in the food sector was published, a detailed analysis presented five papers are related to solid wastes and six papers are related to liquid wastes in the food industry.

\subsection{Procedure for data collection}

The action of collecting data for case studies indicates that the semi-structured interview is the most appropriate in quantitative research, according to Bryman (1995) and Collins \& Hussey (2007). A visit to the factory was made to learn about the manufacturing process of pupunha palm heart. The factory manager and the administrative director were interviewed, and they answered a questionnaire and presented documents related to production. The documentary data survey made it possible to confirm the data provided in the interview (Yin, 2009).

The data survey involved the following questions:

1) How has the $\mathrm{CP}$ adoption in the processing factory of pupunha palm heart contributed to increase economic gains and reduce environmental impacts with waste disposal?

2) How much raw material enters the process?

3) What quantity of raw material is used in palm heart processing?

4) How much waste is generated?

5) What is the selling price of the processed waste?

\subsection{Procedure for data analysis}

The analysis of the data collected in the collection stage uses a quantitative approach since the variables analyzed, in their majority, are identified as measurable (Martins, 2012; Paoli et al. 2013). In the interview, the values related to the investment in a crushing machine of the pupunha bark and the calculation of the annual costs (expenses with the machine's maintenance and consumption of electric energy) were raised. Thus, to evaluate the annual economic gains from the sale of waste, the Return on Investments (ROI) and the return period on invested capital were calculated. According to Martins (2000), the ROI calculation represents the most effective way of measuring an enterprise's degree of success. The ROI calculation and the payback period can be calculated using the equations shown in Table 2.

The mass balance calculation was used to evaluate the amount receivable from the sale of residues generated in the processing of pupunha palm heart. It is calculated by: Mres = Ment - Mpalm (Equation 1).

$M_{\text {res }}=M_{\text {ent }}-M_{\text {palm }}$

Where: $M_{\text {res }}$ - mass of bark residue

$\mathrm{M}_{\text {ent }}$ - input mass of raw material

$\mathrm{M}_{\text {palm }}$ - mass of pupunha palm heart

\section{Case study}

The processing factory of pupunha palm heart is located in Juquiá, located $150 \mathrm{~km}$ from São Paulo City and $250 \mathrm{~km}$ from Curitiba City. The company's primary customers are specialized food distributors and supermarket chains.

The processing process of palm heart is divided into the following steps:

- Collection of trunks in the farms, carried out mainly by small producers pre-registered by the company.

- Unloading the pupunha trunks, transported by trucks, forwarding to the debarking process, separating the residual material (pupunha bark), and the primary product (palm heart billet).

- According to the order requests, cut the palm heart billets (into strips or slices) and fill them in glass pots.

- Cooking, with subsequent storage and sending the product to quarantine, for quality control steps.

- Labeling and shipping of products.

Figure 1 illustrates the processing of pupunha palm heart and the residual generation

With the adoption of CP practices, the processing of residues from palm heart barks was added to the production process, as shown in Figure 1. In this way, the residues are stored for later crushing and transformation into natural fertilizers.

Table 2. Equations for calculating ROI.

\begin{tabular}{ll}
\hline $\begin{array}{l}\text { ROI Evaluation and } \\
\text { Payback Period }\end{array}$ & \% ROI = half-yearly net income / investment \\
& $\begin{array}{l}\text { ROI Period = investment / half-yearly net } \\
\text { income }\end{array}$ \\
\hline
\end{tabular}




\section{Results and discussion}

In this section, the case study results are presented in terms of analysis of the mass balance and evaluation of environmental gains, and the analysis of investments and financial evaluation.

\subsection{Mass balance analysis and environmental gains evaluation}

The factory processes 15 tons of pupunha a day for palm heart production, generating an average of 7.34 tons of waste (pupunha barks), which represents a residual percentage of $48.9 \%$ concerning the total daily value processed in the company. In the researched literature, the solid waste rates found ranged from 50 to $75 \%$ in the Shea production (Adazabra et al., 2016), 15 to $25 \%$ in the Mango Juice Industry (Tesfaye et al., 2018), 100\% of the fruit discarded in the Grape and apple wine industry, and 20 to $25 \%$ in the Avocado farm (Tesfaye et al., 2020).

Considering 220.2 tons of waste are generated monthly, it is possible to state that 2,642.4 tons of waste are generated annually.

The pupunha bark can be used in several agriculture sectors and can be reused as a natural fertilizer to improve the cultivation of different plantations. For this reuse, the main applicable primary process refers to the crushing of the pupunha bark.

Table 3 shows the mass balance calculations of the raw material used and their respective quantities of waste generated after processing the company's product.

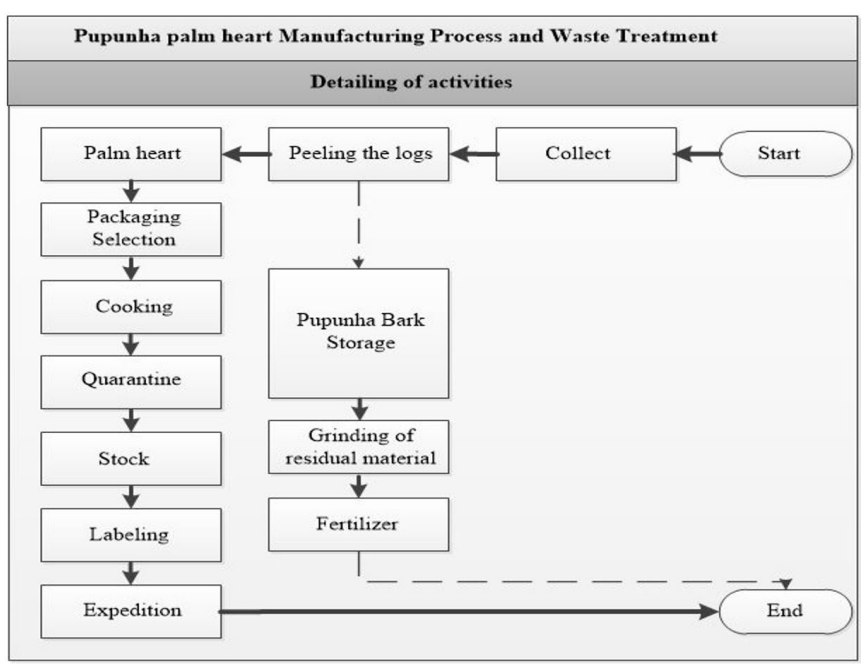

Figure 1. Manufacturing process of pupunha palm heart and residual generation.

Table 3. Mass Balance of Raw Material and Waste Generated.

\begin{tabular}{lcccc}
\hline \multicolumn{1}{c}{ Material } & $\begin{array}{c}\text { Daily } \\
\text { amount } \\
\text { (ton) }\end{array}$ & $\begin{array}{c}\text { Monthly } \\
\text { amount } \\
\text { (ton) }\end{array}$ & $\begin{array}{c}\text { Annual } \\
\text { amount } \\
\text { (ton) }\end{array}$ & $\%$ \\
\hline $\begin{array}{l}\text { Stalks of pupunha } \\
\text { processed }\end{array}$ & 15 & 450 & 5,400 & 100 \\
$\begin{array}{l}\text { Pupunha bark (residue) } \\
\text { Palm heart billets }\end{array}$ & 7.34 & 220.20 & $2,642.40$ & 48.9 \\
\hline
\end{tabular}

The reuse of this residual material corroborates the study of Franco et al. (2019), who prescribe that pupunha has a rapid growth cycle, making it advantageous for productive activities (food products), in addition to the reuse of waste (material with high added value), creating alternatives for mitigation of inadequate disposal.

\subsection{Investment analysis and economic evaluation}

Considering the calculations related to financial gains, the kilogram of processed waste (pupunha bark) receives a value of US\$ 0.0137 , representing a gross annual return of US\$44.920,80. The annual expenses with electricity were US $\$ 8,487.39$, with the maintenance of the area US\$1,529.52, and US $\$ 4,996.04$ was spent with labor. The net annual revenue was US\$29,907.85 through a reduction in annual costs, which are related to the maintenance of the area and expenses with electricity. The investment for acquiring the machine was measured at US\$857.14 in order to validate waste crushing processes (pupunha bark).

Given the findings presented, it was possible to calculate the ROI of $2,445.5 \%$ per year and return on invested capital over 0.06 years or 0.72 months (equivalent to 21.6 days). Table 4 shows the details of the calculations made on the ROI, having as input the investment values about equipment acquisition, the depreciation of 10 years, and the value obtained in the sale of solid waste, after deducting the costs with electricity and maintenance of the area. With these data, taxes had been calculated and discounted, resulting in the value of Annual Cash, and Table 5 shows the period on the return on invested capital.

The processing industries of pupunha palm heart receive the raw material in small batches. It is brought from the farms in trucks that park at the factory in a bay. There, the factory's employees already separate the barks and the palm heart. This procedure keeps the truck stuck, causes congestion at the entrance, and places waste in an inappropriate location. With the adoption of $\mathrm{CP}$ strategies, the first modification was made at the entrance of raw materials, using gondolas, where the raw material is unloaded, and the truck is released. Another modification was made in the trunk's debarking, with the barks placed in a gondola, for processing the waste.

Table 4. Calculation of Return on Investment (ROI).

\begin{tabular}{|c|c|}
\hline $\begin{array}{l}\text { Investment in the implementation of Cleaner } \\
\text { Production }\end{array}$ & US\$ 857.14 \\
\hline Depreciation term (years) & 10 \\
\hline Annual depreciation & US\$ 85.71 \\
\hline Annual Cost Reduction achieved & US\$29,907.85 \\
\hline Annual depreciation & - US\$ 85.71 \\
\hline Basis for calculating Income Tax (IR) & US\$ $29,822.14$ \\
\hline TILP + SCNI (Social Contribution on Profit) & $30 \%$ \\
\hline Annual IT + SCNI value & - US\$ 8,946.64 \\
\hline Annual Net Cost Reduction & US\$ 20,875.50 \\
\hline Annual Depreciation & US\$ 85.71 \\
\hline Annual Cash Generation & US\$ 20,961.21 \\
\hline
\end{tabular}


Table 5. Cash Flow presented over the five-year period.

\begin{tabular}{|c|c|c|c|c|c|c|}
\hline Cash flow & Year 0 (US\$) & Year 1 (US\$) & Year 2 (US\$) & Year 3 (US\$) & Year 4 (US\$) & Year $5(\mathrm{US} \$)$ \\
\hline Investment & -857.14 & & & & & \\
\hline Annual Cash & & $20,961.21$ & $20,961.21$ & $20,961.21$ & $20,961.21$ & $20,961.21$ \\
\hline Cash Flow Total & -857.14 & $20,961.15$ & $20,961.15$ & $20,961.15$ & $20,961.21$ & $20,961.21$ \\
\hline ROI or IRR & & \multicolumn{2}{|c|}{$2,445.5 \%$ per year } & & & \\
\hline PayBack minus $15 \%$ per year & & \multicolumn{2}{|c|}{0.06 year } & & & \\
\hline
\end{tabular}

IRR = Internal Rate of Return.

The novelty at this point of adoption of $\mathrm{CP}$ in the processing factory of pupunha palm heart was gondolas' placement for the entry of raw material and gondolas for placing the barks' residues. The practical advantages were reducing truck times at the factory, better allocating waste, and reducing accidents. Another critical point was the increase in the daily processing capacity of pupunha palm heart, and this corroborates Abou-Elela et al. (2008) and Willers et al. (2014), who introduced changes in the process to increase production.

The use of $\mathrm{CP}$ in the processing factory of pupunha palm heart presented an environmental gain with a decrease of 229.80 tons of waste per month, previously thrown into the environment in a disorderly manner. The reuse of this waste allowed creating a new structure at the factory, with a crushing, packaging, and commercialization unit. This process generated environmental and social gains, with new jobs in a region lacking opportunities.

Adazabra et al. (2016), Denham et al. (2016), Sette et al. (2020), and Zhang et al. (2020) created new activities with the use and processing of waste. This study innovates the state of the art because the adoption of CP practices solved a large amount of waste (in the form of barks) discarded in the environment, generating significant environmental impacts and fines by regulatory agencies. The purchase of a crushing machine allowed the sale of waste as fertilizers for other crops or as nutrients for animal feed. The introduction of equipment or alteration of processes for the treatment and use of waste is efficient, as can be seen in Adazabra et al. (2016), Dvarionienè et al. (2012), and Zhang et al. (2019).

The treatment of waste generated in pupunha palm heart and the $\mathrm{CP}$ adoption required investment in new equipment. The use of ROI calculation can provide more security for managers to invest in new equipment. The novelty in this $\mathrm{CP}$ adoption project was the calculation of ROI, and it is in line with Sette et al. (2020), Wu et al. (2016), and Zhang et al. (2020), who used the economic return to evaluate the implementation of $\mathrm{CP}$ practices and the acquisition of new equipment.

\section{Conclusion}

$\mathrm{CP}$ adoption practices in a processing factory of pupunha palm heart, with changes in the entry process of raw material and the treatment of palm heart barks waste, provided economic and environmental gains by reducing the disposal of waste in the environment. This strategy gave managers the conditions to make more proactive decisions.
Many processing factories of pupunha palm heart installed in Vale do Ribeira are small companies, with a production process without automation, and even inadequate waste treatment, without clear criteria for a destination.

The contribution of this research to the theory was the introduction of ROI calculation as a financial management strategy to support investments that provide environmental gains; for business practice, the placement of gondolas to receive raw material and waste processing; and for the social area, the creation of jobs and the generation of income. The $\mathrm{CP}$ adoption practices in the processing factories of pupunha palm heart added innovation in the production process, increased production, waste use, and economic and environmental gains.

Furthermore, the $\mathrm{CP}$ adoption in the processing sector of pupunha palm heart enables new businesses, such as the development of natural fertilizers, animal feed, raw material for the furniture and handicraft industry.

This study has some limitations. Thus, it is essential to emphasize that the case study was carried out in a single factory that was starting to adopt $\mathrm{CP}$, so the results cannot be generalized for the segment. Additionally, as the focus was on the economic gain generated by using the pupunha bark waste, the reuse of water in the production process was not evaluated.

As a suggestion for future research, evaluating how the wastewater from the production process can be analyzed, treated, and reused is indicated. Furthermore, the realization of multiple cases about the $\mathrm{CP}$ adoption in the processing factories of pupunha palm heart can bring more significant contributions to the study field.

\section{References}

Abou-Elela, S. I., Nasr, F. A., \& El-Shafai, S. A. (2008). Wastewater management in small-and medium-size enterprises: case studies. The Environmentalist, 28(3), 289-296. http://dx.doi.org/10.1007/ s10669-007-9142-4.

Adazabra, A. N., Viruthagiri, G., \& Ravisankar, R. (2016). Cleaner production in the Shea industry via the recovery of Spent Shea Waste for reuse in the construction sector. Journal of Cleaner Production, 122, 335-344. http://dx.doi.org/10.1016/j.jclepro.2016.02.045.

Aschemann-Witzel, J., Giménez, A., \& Ares, G. (2020). Suboptimal food, careless store? Consumer's associations with stores selling foods with imperfections to counter food waste in the context of an emerging retail market. Journal of Cleaner Production, 262, 121252. http://dx.doi.org/10.1016/j.jclepro.2020.121252.

Belniaki, A. C., Michelon, T. B., Vieira, E. S. N., \& Panobianco, M. (2020). Rapid results of peach palm seed viability: a methodological 
proposition for the tetrazolium test. Journal of Seed Science, 42, e202042034. http://dx.doi.org/10.1590/2317-1545v42234727.

Berbari, S. A. G., Prati, P., \& Junqueira, V. C. A. (2008). Qualidade do palmito da palmeira real em conserva. Food Science and Technology (Campinas), 28, 135-141. http://dx.doi.org/10.1590/ S0101-20612008000500021.

Bryman, A. (1995). Research methods and organization studies. London: Routledge.

Chen, W., He, B., Nover, D., Lu, H., Liu, J., Sun, W., \& Chen, W. (2019). Farm ponds in southern China: challenges and solutions for conserving a neglected wetland ecosystem. The Science of the Total Environment, 659, 1322-1334. http://dx.doi.org/10.1016/j. scitotenv.2018.12.394. PMid:31096343.

Clement, C. R., \& Bovi, M. L. A. (1999). Novos mercados para palmitominimamente processado e pronto-para-uso. In Anais do $1^{\circ}$ Seminário do Agronegócio Palmito de Pupunha na Amazônia (pp. 19-23). Porto Velho: EMBRAPA Rondônia.

Collins, J., \& Hussey, R. (2007). Business research methods. New York: McGraw-Hill.

De Laurentiis, V., Hunt, D. V. L., \& Rogers, C. D. F. (2016). Overcoming food security challenges within an energy/water/food nexus (EWFN) approach. Sustainability, 8(1), 1-23. http://dx.doi.org/10.3390/ su8010095.

Denham, F. C., Biswas, W. K., Solah, V. A., \& Howieson, J. R. (2016). Greenhouse gas emissions from a Western Australian finfish supply chain. Journal of Cleaner Production, 112, 2079-2087. http://dx.doi. org/10.1016/j.jclepro.2014.11.080.

Paoli, F. M., Oliveira Neto, G. C., \& Lucato, W. C. (2013). Economic and environmental advantages resulting from utilization of Design for.the Environment (DfE). Espacios (Caracas), 34, 11-21.

Dvarionienė, J., Kruopienè, J., \& Stankevičienè, J. (2012). Application of cleaner technologies in milk processing industry to improve the environmental efficiency. Clean Technologies and Environmental Policy, 14(6), 1037-1045. http://dx.doi.org/10.1007/s10098-012-0518-x.

Elliot, S. (2006). Transdisciplinary perspectives on environmental sustainbility: a resource bsse and framework for it- enabled business transformation appendix A methodological details. Management Information Systems Quarterly, 35(1), 1-13.

Ferreira, V. L. P., Graner, M., Bovi, M. L. A., Draetta, I. S., Paschoalino, J. E., \& Shirose, I. (1982). Comparação entre os palmitos de Guilielma gasipaes Bailey (pupunha) e Euterpe edulis Mart.(juçara). I. Avaliações físicas, organolépticas e bioquímicas. Coletânea do Instituto de Tecnologia de Alimentos, 12(1), 255-272.

Franco, T. S., Potulski, D. C., Viana, L. C., Forville, E., Andrade, A. S., \& Muniz, G. I. B. (2019). Nanocellulose obtained from residues of peach palm extraction (bactris gasipaes). Carbohydrate Polymers, 218(15), 8-19. http://dx.doi.org/10.1016/j.carbpol.2019.04.035. PMid:31221347.

Giannetti, B. F., \& Almeida, C. M. (2006). Ecologia industrial: conceitos, ferramentas e aplicações. São Paulo: Editora Edgard Blücher.

Gil, A. C. (2009). Estudo de caso. São Paulo: Atlas.

Goap, A., Sharma, D., Shukla, A. K., \& Rama Krishna, C. (2018). An IoT based smart irrigation management system using Machine learning and open source technologies. Computers and Electronics in Agriculture, 155(September), 41-49. http://dx.doi.org/10.1016/j. compag.2018.09.040.

Hamner, W. B. (1996, December). What is the relationship among cleaner production, pollution prevention, waste minimization, and ISO 14000. In Proceedings of 1996 First Asian Conference CP in Chemical Industry. Japan: National Cleaner Production Centre.
Ianovali, D., Adams, C., Ribeiro, A. A., Fo., \& Khatounian, C. A. (2018). Produtividade agrícola e mudanças socioculturais: a agricultura quilombola no Vale do Ribeira-SP Brasil. Desenvolvimento e Meio Ambiente, 49, 221-238. http://dx.doi.org/10.5380/dma.v49i0.54697.

Ingrao, C., Faccilongo, N., Di Gioia, L., \& Messineo, A. (2018). Food waste recovery into energy in a circular economy perspective: A comprehensive review of aspects related to plant operation and environmental assessment. Journal of Cleaner Production, 184, 869892. http://dx.doi.org/10.1016/j.jclepro.2018.02.267.

Jabbour, C. J. C. (2010). Non-linear pathways of corporate environmental management: a survey of ISO 14001-certified companies in Brazil. Journal of Cleaner Production, 18(12), 1222-1225. http://dx.doi. org/10.1016/j.jclepro.2010.03.012.

Jin, B., Zepf, F., Bai, Z., Gao, B., \& Zhu, N. (2016). A biotech-systematic approach to select fungi for bioconversion of winery biomass wastes to nutrient-rich feed. Process Safety and Environmental Protection, 103, 60-68. http://dx.doi.org/10.1016/j.psep.2016.06.034.

Kapp, E. A., Pinheiro, J. L., Raupp, D. D. S., \& Chaimsohn, F. P. (2003). Tempo de preservação de tolete de palmito pupunha (Bactris gasipaes) minimamente processado e armazenado sob refrigeração. Ciências Exatas e da Terra. Ciências Agrárias e Engenharias, 9(3), 51-57.

Liu, C., Hotta, Y., Santo, A., Hengesbaugh, M., Watabe, A., Totoki, Y., Allen, D., \& Bengtsson, M. (2016). Food waste in Japan: trends, current practices and key challenges. Journal of Cleaner Production, 133, 557-564. http://dx.doi.org/10.1016/j.jclepro.2016.06.026.

Mannan, M., Al-Ansari, T., Mackey, H. R., \& Al-Ghamdi, S. G. (2018). Quantifying the energy, water and food nexus: a review of the latest developments based on life-cycle assessment. Journal of Cleaner Production, 193, 300-314. http://dx.doi.org/10.1016/j. jclepro.2018.05.050.

Marconi, M. D. A., \& Lakatos, E. M. (2010). Fundamentos de metodologia científica (7. ed.). Rio de Janeiro: Atlas.

Martins, E. (2000). Contabilidade de custos (7. ed.). São Paulo: Atlas.

Martins, R. A. (2012). Abordagens quantitativas e qualitativas. In P. A. C. Miguel (Org.), Metodologia de pesquisa em engenharia de produção e gestão de operações (2. ed.) Rio de Janeiro: Elsevier.

Massote, C. H. R., \& Santi, A. M. M. (2013). Implementation of a cleaner production program in a Brazilian wooden furniture factory. Journal of Cleaner Production, 46, 89-97. http://dx.doi.org/10.1016/j. jclepro.2012.09.004.

Medici, M., Canavari, M., \& Toselli, M. (2020). Interpreting environmental impacts resulting from fruit cultivation in a business innovation perspective. Sustainability, 12(23), 9793. http://dx.doi.org/10.3390/ su12239793.

Mossanek, E. A. O., Wendling, I., Koehler, H. S., \& Zuffellato-Ribas, K. C. (2014). Indução de perfilhos em mudas de pupunheira. Pesquisa Florestal Brasileira, 34(77), 39-48. http://dx.doi.org/10.4336/2014. pfb.34.77.549.

Neugebauer, M., \& Sołowiej, P. (2017). The use of green waste to overcome the difficulty in small-scale composting of organic household waste. Journal of Cleaner Production, 156, 865-875. http:// dx.doi.org/10.1016/j.jclepro.2017.04.095.

Oliveira, G. C., No., Shibao, F. Y., \& Godinho Filho, M. (2016). The state of research on cleaner production in Brazil. Revista de Administração de Empresas, 56(5), 547-577. http://dx.doi.org/10.1590/s0034759020160508 .

Oliveira, J. R., Silva, H. M., Abreu, L. P., \& Fernandes, S. R. (2013). Use of a warm mix asphalt additive to reduce the production temperatures and to improve the performance of asphalt rubber 
mixtures. Journal of Cleaner Production, 41, 15-22. http://dx.doi. org/10.1016/j.jclepro.2012.09.047.

Ormenese, R. D. C. S. C., Berbari, S. A. G., \& Reis, M. G. D. (2016). Correlating physical and sensory texture measurements of hearts of palm in conserve. Food Science and Technology (Campinas), 36(4), 679-685. http://dx.doi.org/10.1590/1678-457x.13216.

Ramos, A. R., Ferreira, J. C. E., Kumar, V., Garza-Reyes, J. A., \& Cherrafi, A. (2018). A lean and cleaner production benchmarking method for sustainability assessment: A study of manufacturing companies in Brazil. Journal of Cleaner Production, 177, 218-231. http://dx.doi. org/10.1016/j.jclepro.2017.12.145.

Sáez-Martínez, F. J., Lefebvre, G., Hernández, J. J., \& Clark, J. H. (2016). Drivers of sustainable cleaner production and sustainable energy options. Journal of Cleaner Production, 138(Pt 1), 1-7. http://dx.doi. org/10.1016/j.jclepro.2016.08.094.

Sette, P., Fernandez, A., Soria, J., Rodriguez, R., Salvatori, D., \& Mazza, G. (2020). Integral valorization of fruit waste from wine and cider industries. Journal of Cleaner Production, 242, 118486. http://dx.doi. org/10.1016/j.jclepro.2019.118486.

Silva, F. A. M., Prado, J. E., \& Silva, R. B. (2009). Aproveitamento de resíduos da agroindústria do palmito no vale do Ribeira. Revista Brasileira de Agroecologia, 4(2), 2595-2598.

Tesfaye, T., Ayele, M., Ferede, E., Gibril, M., Kong, F., \& Sithole, B. (2020). A techno-economic feasibility of a process for extraction of starch from waste avocado seeds. Clean Technologies and Environmental Policy, (In Press). http://dx.doi.org/10.1007/s10098-020-01981-1.

Tesfaye, T., Johakimu, J. K., Chavan, R. B., Sithole, B., \& Ramjugernath, D. (2018). Valorisation of mango seed via extraction of starch: preliminary techno-economic analysis. Clean Technologies and Environmental Policy, 20(1), 81-94. http://dx.doi.org/10.1007/ s10098-017-1457-3.

Willers, C. D., Ferraz, S. P., Carvalho, L. S., \& Rodrigues, L. B. (2014). Determination of indirect water consumption and suggestions for cleaner production initiatives for the milk-producing sector in a Brazilian middle-sized dairy farming. Journal of Cleaner Production, 72, 146-152. http://dx.doi.org/10.1016/j.jclepro.2014.02.055.

Wu, D., Cao, Y., Chen, J., Gao, H., Ye, X., Liu, D., \& Chen, S. (2016). Feasibility study on water reclamation from the sorting/grading operation in Mandarin orange canning production. Journal of Cleaner Production, 113, 224-230. http://dx.doi.org/10.1016/j. jclepro.2015.12.047.

Yin, R. K. (2009). Case study research: design and methods ( $4^{\text {th }}$ ed.). Sage, Newbury Park.

Zanini, N. C., Barbosa, R. F. S., de Souza, A. G., Rosa, D. S., \& Mulinari, D. R. (2020). Revaluation of Australian palm residues in polypropylene composites: Statistical influence of fiber treatment. Journal of Composite Materials, 55(6), 813-826. http://dx.doi. org/10.1177/0021998320960534.

Zhang, C., Yang, H. Q., \& Wu, D. J. (2019). Study on the reuse of anaerobic digestion effluent in lactic acid production. Journal of Cleaner Production, 239, 118028. http://dx.doi.org/10.1016/j. jclepro.2019.118028.

Zhang, C., Ren, H., \& Zhong, C. (2020). Economical production of vitamin K2 using wheat starch wastewater. Journal of Cleaner Production, 270, 122486. http://dx.doi.org/10.1016/j.jclepro.2020.122486. 